Bolm Inst. oceanogr., S Paulo, 33(1):79-91, 1985

\title{
SESSILE CILIATES ON ARTIFICIAL SUBSTRATA SUBMERGED IN A POLLUTED ESTUARY (SANTOS, SP, BRAZIL)
}

\author{
Verena Rapp de ESTON
}

Instituto Oceanogräfico da Universidade de São Paulo

\begin{abstract}
Synopsis
Primary growth was analysed on artificial substrata submerged at three sites of the Santos estuary (State of São Paulo, Brazil). Research on sessile ciliates was emphasized because they were the most conspicuous organisms of the primary growth developed along this estuary. Zoothamnium commune dominated near the headwaters of the estuary, where the greatest amount of suspended matter in the water was found. Ephelota gemmipara dominated downstream. Although short time variability was observed in the colonization of substrata submerged on subsequent days, seasonal patterns could be determined. These patterms were characterized by a greater number of rare species of sessile ciliates, and a higher density of the most frequent ones, during spring and summer.

Descriptors: Periphyton, Artificial substrata, Estuaries, Pollution, Sessile ciliates, Ciliata, Santos-SP, Southern Brazilian coast.

Descritores: Perifiton, Substratos artificiais, Estuärios, Poluição, Ciliados sésseis, Ciliata, Santos-SP, Costa sul-Brasil.
\end{abstract}

\section{Introduction}

Associations of protozoa or diatoms have been used by several authors to define a polluted environment, since the abundance and composition of these organisms may change quick1y according to water quality (Patrick et al., 1954; Heulekian \& Crosby, 1956; Genovese \& Gangemi, 1966; Burbank \& Spoon, 1967; Persoone, 1968; Wilbert, 1969; Parrish \& Lucas, 1970; Relini et al., 1976; Cairns Jr et al., 1978; Henebry \& Cairns Jr, 1980; Marcus, 1980). The primary colonizers of substrata, either natural or artificial surfaces, are protozoa, diatoms, bacteria, and eventually macroscopic organisms (Persoone 1968; 1971). Artificial substrata have been used for quantitative studies and for comparisons of the primary growth between environments, since natural surfaces are irregular, rugose, and not favorable for quantitative analysis (Slädecková, 1962).

In the present paper, sessile ciliates were studied to determine changes in the community structure with distance frompollution sources as well as temporal variation, since they are the most conspicuous organisms of the primary growth developed in the Santos estuary.

Publ. n. 622 do Inst. oceanogr. da Usp.

\section{Material and methods}

\section{Study site}

Santos estuary is placed at southern Brazilian coast $\left(23^{\circ} 56^{\prime} \mathrm{S}-46^{\circ} 20^{\prime} \mathrm{W}\right)$ (Fig. 1). It is a coastal plain estuary which receives coarse sediments carried by the rivers descending from "Serra do Mar" mountains (Goldenstein, 1972). The fluvial system is the main source of the existing pollution: the estuary receives urban and industrial effluents, presenting a decreasing gradient of nitrate, phosphate, mercury, pesticides, and sediments in suspension in the water from the headwaters downstream (Tommasi, 1979).

\section{Methods}

Three collection sites positioned in a transect along the estuary were chosen (Fig. 1). Samples were obtained every 45-60 days from May 1979 to March 1980 at all three sites. An experiment related to short time variability was made at site C in January 1980, for 8 consecutive days. Microscope cover slips $(22 \times 22 \mathrm{~mm})$, used as surfaces for colonization, were maintained in a vertical position fastened by acrylic supports. These supports were placed $0.5 \mathrm{~m}$ deep in the water anchored to local piers, where they remained for 5 days. Pairs of cover slips were held 
Bolm Inst. oceanogr., S Paulo, 33(1), 1985

together in order to avoid colonization on both sides. Immersion time was previously determined in order to sample a community that represented the primary growth. Once removed from the water, four replicas of cover slips of each collecting site were fixed with Bouin and stained using the Protargol technique, following the methodology modified by Eugene B. Small (Laboratory notes in protozoology, Fall 1976, Dept. Zoology, Univ. Maryland, MD, U.S.A.).

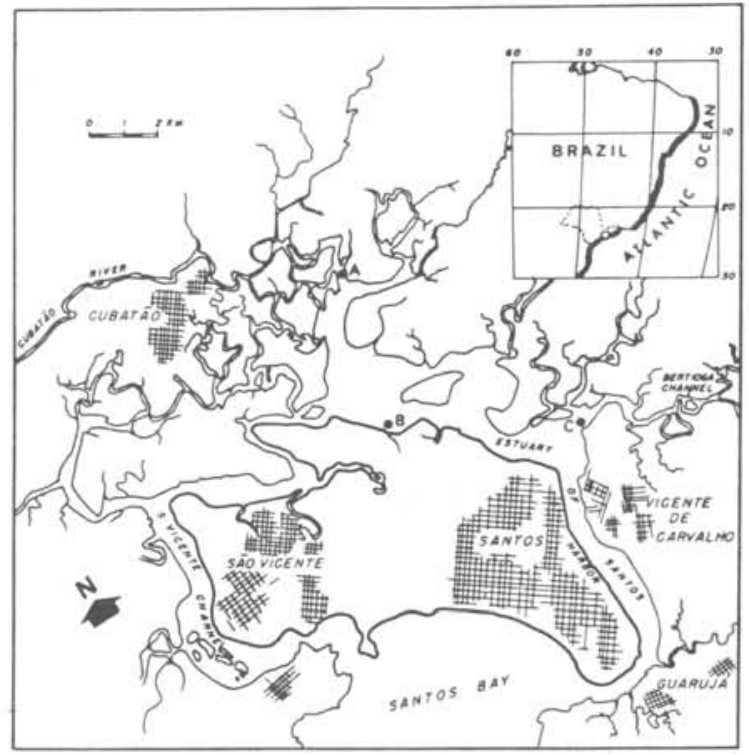

Fig. I - Santos estuary, with position of collection sites (A, B and C).

Ten percent of the surface of the cover slips was established as the minimum area necessary to quantify the sessile species with random distribution, sampled in random plots of $1 \mathrm{~mm}^{2}$. Rare species or species with gregarious distribution were counted on the total area of the cover slips. Since points of fixation of the organisms to the substrata were counted, the number of individuals of colonial species is underestimated. Vagile ciliates were not quantified. Morisita's similarity coefficient $\mathrm{C} \lambda$ (Grassle \& Smith, 1976) was calculated between samples, and the results were clustered by the weighted pair-group method using arithmetic averages (Davis, 1973; Sneath \& Sokal, 1973).

Measurements of salinity, temperature, transparency, dissolved oxygen, suspended matter (inorganic and organic), chlorophy11- $a$ and pheophytin- $a$ of the water were estimated at the collection sites by the time of placement of the substrata and a fortnight later. Duplicate samples of the last four parameters were averaged. Indexes of rainfall were obtained from Instituto Nacional de Meteorologia (7ọ distrito), Ministério da Agricultura.

\section{Results \\ Ciliates}

Two types of association were formed by the sessile ciliates in the Santos estuary: 1) the primary growth at sampling site A, where Zoothamnium commune dominated; 2) primary growth at sites B and C, where Ephelota gemmipara predominated. The dominance, either of $Z$. commune or of $E$. gemmipara, was responsable for setting apart site $A$ from sampling sites $B$ and $C$ when data were clustered (Figs 2-3).

Zoothamnium commune was found on all substrata submerged at the three collecting sites. It was the dominant species at site A, followed by

Zoothamnium sp (sensu Kahl, 1935) (Table $1)$. At site B Z . commune also occurred in great numbers although in rather less amount than Ephelota gemmipara (Table 2). Small colonies of Zoothamnium were more commonly found than large ones, and a decrease in the size of the colonies towards the mouth of the estuary was observed. Few large colonies of these species, with 500 to 1000 zooids, were observed during October and December of 1979 at site A. At site B the bigger colonies had 250 individuals (December of 1979) while at site C the maximum number of zooids per colony was 50 (December of 1979).

Ephelota gemmipara was the dominant species in almost every sample obtained at sites B and C (Tables 2-3). Encysted individuals predominated over non encysted ones in about $50 \%$ of the substrata submerged at these two places. At site A only 4 individuals of this species were observed during the sampling period, all encysted (Table 1). Some of the cysts were found parasitezed; parasitism of $E$. gemmipara by Hypocoma sp was observed in May, December, January, and March at sampling sites $B$ and $C$, periods of great abundance of $E$. gemmipara. 


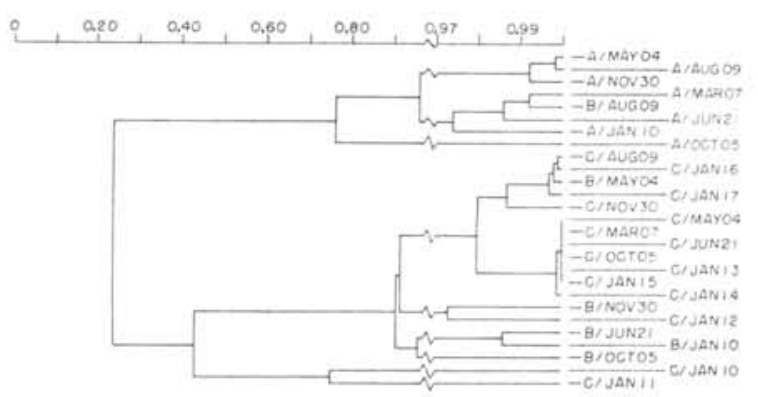

Fig. 2 - Results of the cluster analysis between substrata submerged at the collection sites in different periods of the year. Data of the replicate samples were gathered. Date of submersion of the substrata is indicated.
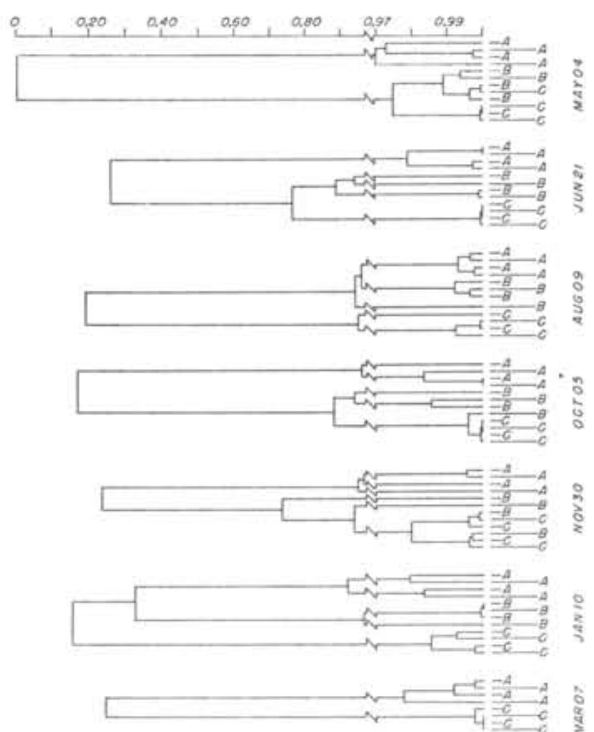

Fig. 3 - Results of the replicate samples of the substrata submerged at the collection sites clustered by the time of the year. Date of submersion of the substrate is indicated.

In the short time variability experiment Acineta tuberosa dominated followed by $Z$. commune in great numbers on the cover slips submerged on January 10 and 11 at site C. From January 11 onwards, the numbers of $E$. gemmipara started to increase while $Z$. commune decreased. From January 12 on, the number of A. tuberosa decreased as well while $E$. gemmipara became dominant (Table 4).

High densities of sessile ciliates and a greater number of rare species were observed during spring and summer. The heavier colonization periods were observed from October to March, with more than 1000 points of fixation $/ \mathrm{cm}^{2}$ (Fig. 4). In addition to Zoothamnium commune, both Acineta tuberosa and Zoothamnium sp. (sensu Kah1, 1935) occurred in great numbers during october at site $A$. In the other sampling periods only $Z$. commune was dominant at this collecting site (Table 1). Ephelota gemmipara shared its dominance with $A$. tuberosa during December and with $Z$. commune during January at site $B$, and with $A$. tuberosa and $Z$. commune during January at sampling site C (Tables 2-3). A change in the density of the sessile ciliates was observed on substrata submerged at site $\mathrm{C}$ on consecutive days during January of 1980 (Fig. 4B).

The greatest number of species was found during October at site $\mathrm{B}$ and during December at sites A and C (Fig. 5). Individuals of Acineta sp, Cothurnia $\mathrm{sp}$, Epistylis sp, Platycola gracilis, $P$. regularis, Podoprhya fixa, Pyxicola socialis, Vaginicola crystallina, Vorticella sp 1 and Vorticella sp 2 were found only in the warmer months and in smal1 numbers. Cothurnia maritima and Vorticella nebulifera were found in varying numbers troughout the year (Tables 1-4).

Vagile ciliates such as Hemiophrys, Hypocoma, Thigmogaster, Trochilia and some unidentified Gymnostomata, were found at all sampling sites. Herbivores, such as Nassula and Chilodonella (Fauré-Fremiet, 1961; Dragesco, 1962; Bick, 1972), were never present at sampling site A. Great numbers of certain vagile ciliates occurred occasionally although never surpassing the amount of the sessile ones: Hemiophrys at site A in October;

Thigmogaster at sites A and B in May and January, and at A also in October, December and March; Hypocoma at sites B and $\mathrm{C}$ in May, and at $\mathrm{C}$ also in December and January; Dileptus at $\mathrm{C}$ in May; and Chilodonella at site C in January. Although the number of species of vagile ciliates increased towards the mouth of the estuary, predators of peritrichs, such as Dileptus and Hemiophrys (Dragesco, 1962; Curds, 1969; Smal1, 1973), were sporadically found in great numbers both at the headwaters and downstream. 
Table 2 - Density of sessile ciliates on artificial substrata submerged at site B throughout the sampling period.

\begin{tabular}{|c|c|c|c|c|c|c|c|c|c|c|c|c|c|c|c|c|c|c|c|c|c|c|c|c|}
\hline \multirow{2}{*}{$\frac{\begin{array}{c}\text { Period of } \\
\text { submersion }\end{array}}{\text { Species }}$} & \multirow[b]{2}{*}{1290} & \multicolumn{3}{|c|}{ May 04-09 } & \multicolumn{4}{|c|}{ Jun $21-26$} & \multicolumn{4}{|c|}{ Aug 23-28 } & \multicolumn{4}{|c|}{ Oct $05-10$} & \multicolumn{4}{|c|}{ Nov 30-Dec 05} & \multicolumn{4}{|c|}{$\operatorname{Jan} 10-15$} \\
\hline & & 2200 & 3700 & 1761 & 404 & 653 & 318 & 285 & 48 & - & - & 13 & 4040 & 4880 & 3020 & 3830 & 2180 & 2540 & 4150 & 3070 & 4830 & 4620 & 3370 & 2550 \\
\hline Pedophrya Lixa & - & - & - & - & - & - & - & - & - & - & - & - & 1 & - & - & - & 4 & 5 & - & - & - & - & - & - \\
\hline Acincta tuberosa & 3 & 2 & 8 & 6 & 17 & 4 & 46 & 67 & 13 & 6 & 2 & - & 244 & 187 & 258 & 301 & 2412 & 181 & 302 & 806 & 7 & 25 & 23 & 63 \\
\hline Acincta sp & - & - & - & - & - & - & $\cdot$ & $\cdot$ & $\cdot$ & - & $\cdot$ & - & - & - & - & - & - & - & - & - & - & - & - & - \\
\hline Epistylis sp & - & - & - & - & - & - & - & - & - & - & - & - & 6 & 2 & 3 & 4 & $\cdot$ & - & - & - & - & - & 3 & - \\
\hline Vorticella nebulifera & 12 & 32 & 25 & 95 & 25 & 1 & 21 & 17 & 11 & 40 & 42 & 127 & 16 & 10 & 182 & 19 & 4 & 2 & 18 & 12 & 366 & 448 & 351 & 126 \\
\hline Verticella sp 1 & 58 & 19 & 14 & 16 & 2 & - & - & - & - & - & - & - & 3 & - & 2 & - & 55 & - & - & 1 & 6 & 7 & 13 & - \\
\hline Verticella sp 2 & $\cdot$ & $\cdot$ & - & - & - & - & - & - & - & - & - & - & - & - & - & - & - & - & - & - & - & - & - & - \\
\hline Verticella sp 3 & 1 & - & - & - & - & - & - & - & - & $\cdot$ & - & - & $\cdot$ & - & 1 & - & - & - & - & - & - & - & - & - \\
\hline Zecthamnium commune & 152 & 472 & 360 & 134 & 187 & 196 & 271 & 321 & 474 & 452 & 497 & 364 & 921 & 78 & 1479 & 1311 & 822 & 1066 & 319 & 351 & 2560 & 1020 & 1370 & 1380 \\
\hline Zeothamnium sp & 88 & 28 & 48 & 36 & - & - & - & - & 25 & 54 & 24 & 17 & 1303 & 102 & 38 & 70 & - & - & 1 & - & - & - & - & - \\
\hline Cothurnia maritima & 91 & 144 & 74 & 62 & 104 & 18 & 10 & 19 & 18 & 11 & 19 & 8 & 42 & 145 & 131 & 24 & 15 & 20 & 11 & 8 & 85 & 827 & 130 & 186 \\
\hline Cothurnia sp & - & - & 1 & 1 & - & - & - & 1 & - & 2 & - & $\cdot$ & 1 & - & 1 & 1 & 1 & - & 1 & - & - & $\cdot$ & - & - \\
\hline Platycola aracilis & - & - & - & $\cdot$ & - & - & - & - & - & - & - & - & - & - & - & $\cdot$ & - & - & $\cdot$ & 1 & - & - & - & - \\
\hline Platycola regularis & - & - & - & - & - & - & - & - & - & - & - & - & $\cdot$ & - & $\cdot$ & $\cdot$ & - & - & - & - & - & - & - & - \\
\hline Pyxicola socialis & - & - & - & - & - & - & - & - & - & - & - & $\cdot$ & 1 & - & - & - & - & 1 & - & - & - & - & - & - \\
\hline Vaqinicola crystallina & - & - & - & - & - & - & - & - & - & $\cdot$ & - & - & 5 & - & 2 & - & 71 & 25 & 1 & 9 & 64 & 75 & 26 & 67 \\
\hline Total density (N) & 1695 & 2897 & 4230 & 2111 & 739 & 872 & 666 & 710 & 589 & 565 & 584 & 529 & 6583 & 5404 & 5117 & 5560 & 5564 & 3840 & 4803 & 4258 & 7918 & 7022 & 5286 & 4372 \\
\hline $\mathrm{N} / \mathrm{cm}^{2}$ & 385 & 658 & 961 & 480 & 168 & 198 & 151 & 161 & 134 & 128 & 133 & 120 & 1496 & 1228 & 1163 & 1264 & 1254 & 873 & 1092 & 968 & 1799 & 1596 & 1201 & 994 \\
\hline
\end{tabular}


Table 4 - Density of sessile ciliates on artificial substrata submerged in January of 1980 at site $C$ for 8 consecutive days

\begin{tabular}{|c|c|c|c|c|c|c|c|c|c|c|c|c|c|c|c|c|c|c|c|c|c|c|c|c|c|c|c|c|c|c|c|c|}
\hline \multirow{2}{*}{ 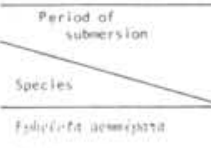 } & \multicolumn{5}{|c|}{$\operatorname{san} 10-15$} & \multicolumn{4}{|c|}{$\operatorname{Jan} 11-16$} & \multicolumn{4}{|c|}{$\tan 12-17$} & \multicolumn{4}{|c|}{$\operatorname{san} 13 \cdot 18$} & \multicolumn{3}{|c|}{$\operatorname{san} 14-19$} & \multicolumn{4}{|c|}{$\tan 15-20$} & \multicolumn{4}{|c|}{$\operatorname{Jan} 16-21$} & \multicolumn{4}{|c|}{$\operatorname{Jan} 17-22$} \\
\hline & 5 & 9 & 9 & 12 & 3540 & 2190 & 6300 & 3222 & 5100 & 6320 & 5000 & 11880 & 14500 & 11160 & 14520 & 13240 & 7960 & 3700 & 1400 & 1760 & 5340 & 3520 & 3690 & 6650 & 4490 & 1630 & & 899 & 1221 & 1968 & 3437 & 1105 \\
\hline Podophtuat ated & & & & & 6 & 2 & 25 & 14 & 3 & 11 & 3 & 4 & $\cdot$ & 1 & & 1 & & & - & 1 & & & . & & $\cdot$ & & . & 1 & $\cdot$ & & $\cdot$ & - \\
\hline Acimen fuberesa & 4185 & 2460 & 4704 & 3126 & 7606 & 3191 & 2238 & 5519 & 3621 & 2940 & 1050 & 3500 & 201 & 156 & 431 & 292 & 155 & 17 & 180 & 25 & $\pi$ & 52 & 10 & 54 & 1 & & & 9 & 2 & 67 & 15 & $\imath$ \\
\hline Acimeta so & & & & & - & & - & & & - & & - & & & & - & - & & . & & & & - & & - & - & & . & & & & . \\
\hline ferstivis so & & & & & & & & & & & & $\cdot$ & & & & & & & - & & & . & - & & . & & . & & . & & - & . \\
\hline 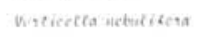 & 21 & 17 & 26 & 49 & 68 & 102 & 26 & 136 & 31 & 96 & 65 & 61 & 13 & 11 & 6 & ? & - & 3 & " & s & 5 & ss & 5 & is & 148 & 3 & ' & 23 & 27 & 26 & 21 & 205 \\
\hline menticenters sp 1 & - & - & - & & & & & - & - & & - & - & - & - & - & & - & - & - & - & - & - & & & & - & & - & . & . & $=$ & \\
\hline warticeftea sp 2 & & & & & - & & & & . & . & . & . & & & & - & . & & - & & . & - & . & . & - & & - & & & & & . \\
\hline Denticerta so 3 & & & & & & & - & & & & & & & & - & . & & & & - & . & . & - & - & . & - & & - & & . & . & \\
\hline 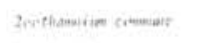 & 4110 & 410 & 380 & 380 & 459 & 300 & $m 2$ & 376 & 159 & 337 & 58 & 161 & 114 & so & 78 & 38 & $n$ & 62 & 97 & 116 & 98 & 283 & 195 & 185 & 183 & 249 & 369 & 197 & 94 & 135 & 242 & 218 \\
\hline zwethatsilum sp & & - & - & & 3 & 2 & - & $\cdot$ & 1 & & & - & $\cdot$ & $\cdot$ & & . & & & - & - & - & - & . & - & & & & - & . & & . & \\
\hline 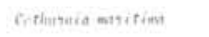 & 13 & 208 & 11 & 41 & ' & , & 5 & - & - & , & 1 & 1 & 1 & 10 & 1 & 1 & 2 & 34 & is & I & & , & 20 & 1 & 2 & 17 & 39 & s & - & & 38 & q \\
\hline cefferstria so & - & - & - & - & . & - & 1 & & . & - & & . & . & - & - & . & - & $\cdot$ & - & . & . & 4 & 1 & 2 & & & & . & 6 & 21 & , & 2 \\
\hline Prativecto anaricios & - & - & & - & & & 1 & & & - & & & & - & - & - & - & & - & - & - & & - & & 5 & s & - & . & & & . & - \\
\hline Peatiperita ceautasis & ${ }^{2}$ & & & 8 & & ' & 2 & ' & 3 & ' & & & 2 & & . & & - & ' & 2 & - & 4 & 10 & 8 & 8 & 2 & 2 & 6 & 12 & 40 & 13 & 21 & 6 \\
\hline Pipecenth seciatis & - & & & & & - & & & & - & & & & & - & & - & & & - & - & - & - & & & . & 1 & & & & . & , \\
\hline 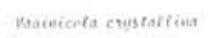 & & & & & & & & & & & & & & & & & - & - & - & & - & . & . & - & . & , & , & & & . & . & . \\
\hline Total density (s) & 5336 & 3104 & 5130 & 3616 & 11683 & 5785 & $9330=$ & 9268 & 8918 & 9714 & 8177 & 15607 & 14831 & 11388 & 15036 & 13579 & 8196 & 3817 & 1705 & 1908 & $5 s 21$ & 3936 & 3929 6 & 6925 & ${ }_{4831}$ & 1907 & 586 & 1146 & 1390 & 2236 & $3 m$ & 1554 \\
\hline$w / \mathrm{men}^{3}$ & 1213 & 705 & 1166 & 822 & 2655 & 1315 & 2120 & 2106 & 2027 & 2208 & 1858 & 3547 & 3371 & 2588 & 3417 & 3086 & 1862 & 867 & 387 & 434 & 1255 & 896 & 893 & 1574 & 1098 & 433 & 133 & 260 & 316 & 508 & 858 & 353 \\
\hline
\end{tabular}



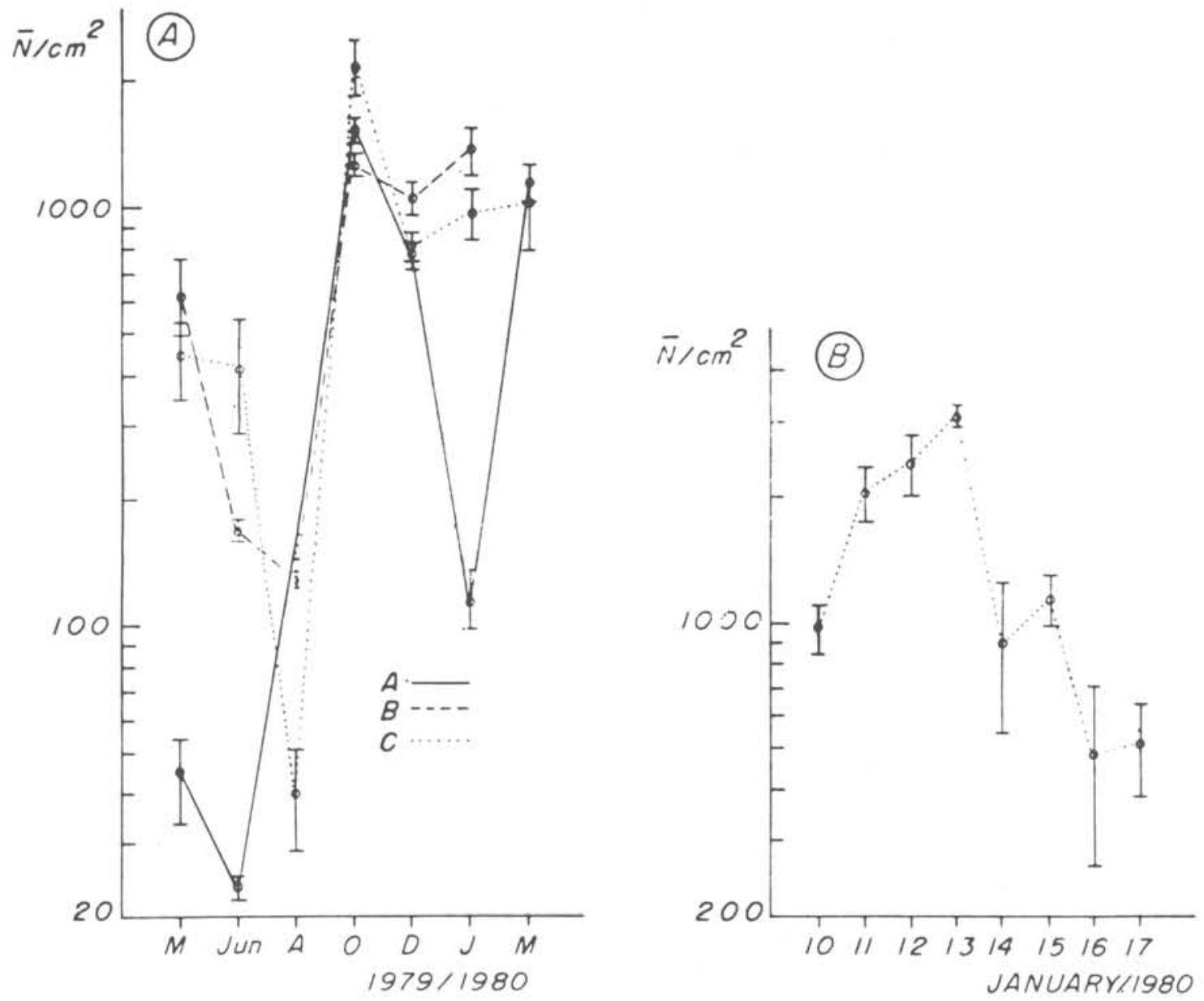

Fig. 4 - Mean number of points of fixation of the sessile ciliates by substratum area $\left(\bar{N} / \mathrm{cm}^{2}\right)$. Ears indicate standard deviation of the mean. A) Seasonal variability at the sampling sites; B) Daily variability at site C of collection. Date of submersion of the substrata is indicated.
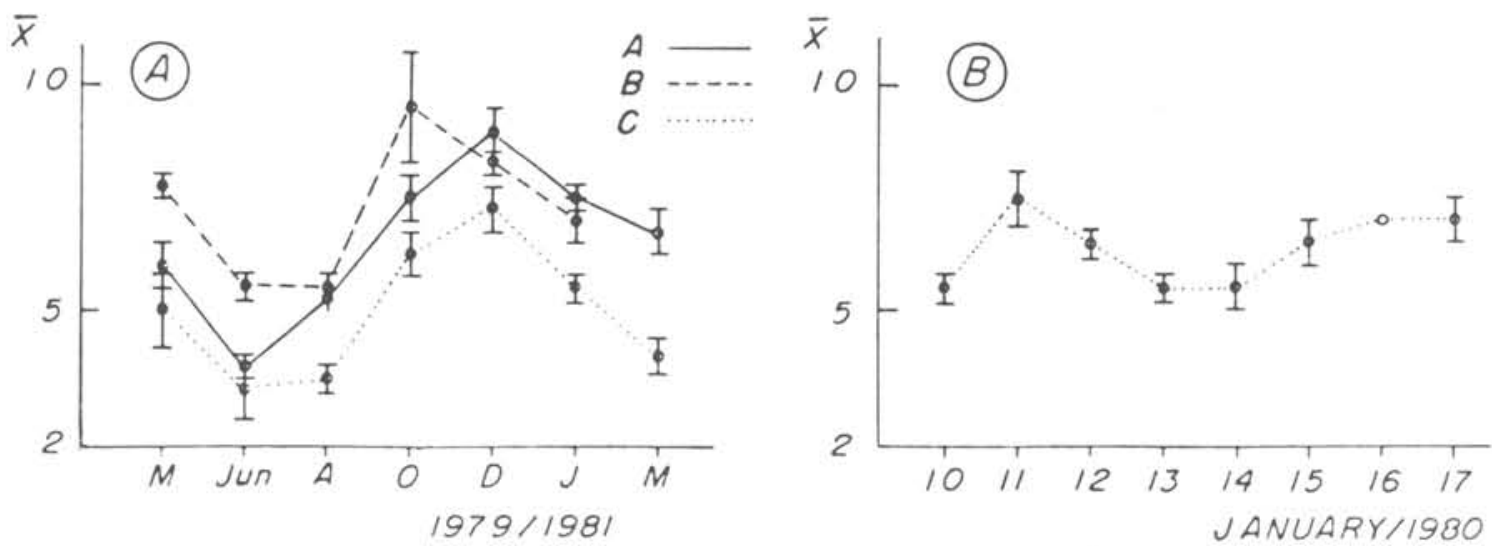

Fig. 5 - Mean number of species found $(\bar{x})$. Bars indicate standard deviation of the mean. A) Seasonal variability at the sampling sites; B) Daily variability at site C of collection. Date of submersion of the substrata is indicated. 


\section{Environmental factors}

Temperature of the water presented a seasonal pattern, with maximum values during summer (November to March), from 24 to $29^{\circ} \mathrm{C}$, and minimum values during winter (June to August), from 19 to $22^{\circ} \mathrm{C}$ (Fig. 6). Annual fluctuations of temperature were about $10^{\circ} \mathrm{C}$. An oscillation of $5^{\circ} \mathrm{C}$ was observed in the daily samples obtained during January of
1980 at collection site C. Salinity varied from 1.6 to $12.1 \%$ at collecting site A, from 3.7 to $22,1 \%$ at site $B$ and from 4.1 to $23.4 \%$ at site $C$. During the short time variability experiment, salinity values at site $C$ varied from 4.1 to $21.4 \%$ (Fig. 6). Minimum rainfall indexes were registered in June and August while the maximum one was attained in November (Table 5).
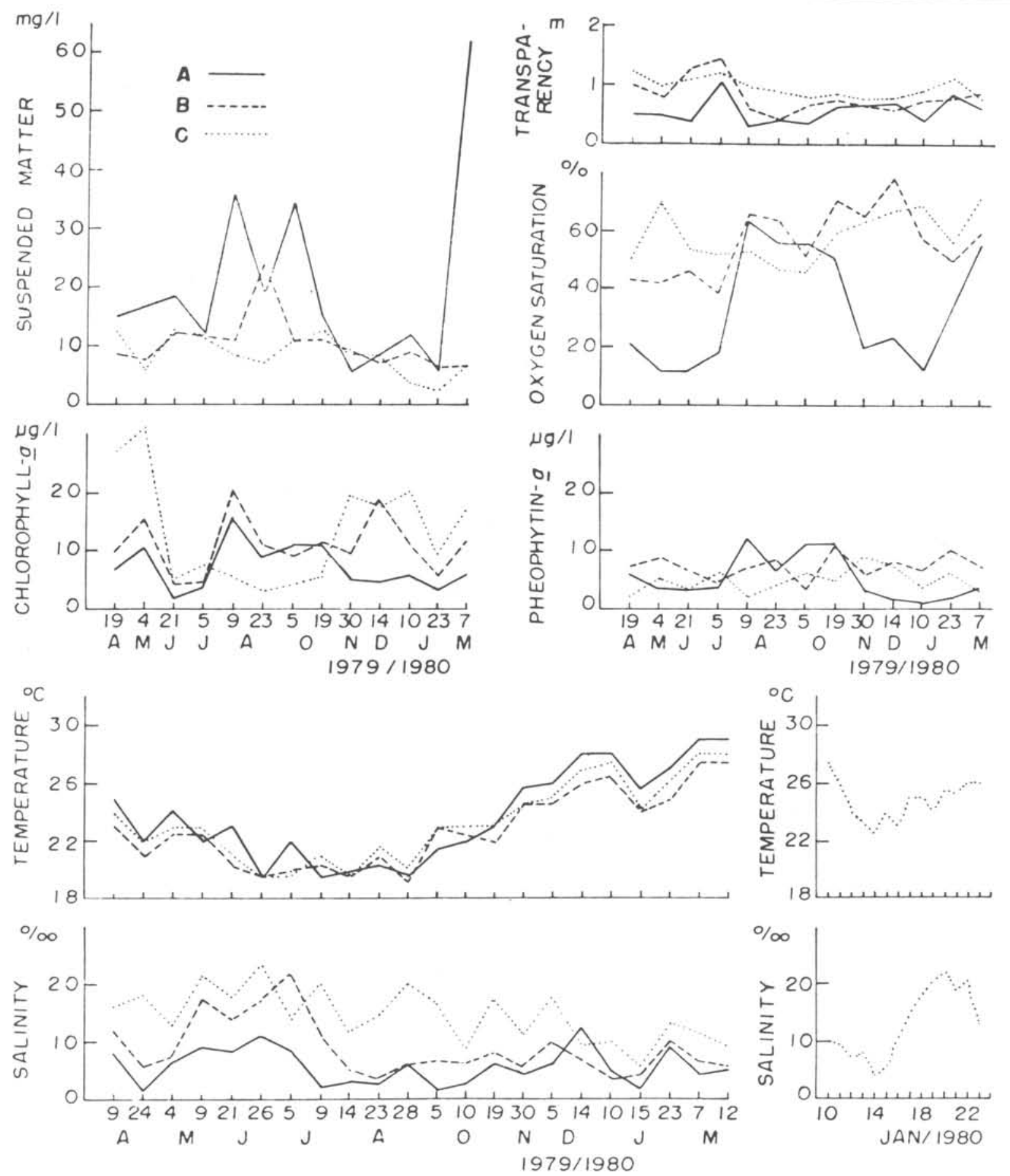

Fig. 6 - Environmental data at collection sites. 


\section{Table 5 - Monthly indexes of rainfall (data granted from Institu- to Nacional de Meterorolo- gia - 7? distrito - Minis- tërio da Agricultura)}

\begin{tabular}{lc}
\hline Date & Indexes of rainfall (mm) \\
\hline May 1979 & 103.7 \\
Jun & 56.1 \\
Jul & 159.3 \\
Aug & 57.8 \\
Sep & 234.7 \\
Oct & 147.0 \\
Nov & 314.4 \\
Dec & 256.6 \\
Jan 1980 & 255.7 \\
Feb & 294.4 \\
Mar & 260.3 \\
\hline
\end{tabular}

The amount of suspended matter decreased from the headwaters to the mouth of the estuary (Fig. 6). Inorganic matter represented the bulk of the suspended matter, and varied from 4.7 to $57.1 \mathrm{mg} / 1$ at site A, from 4.9 to 20.2 $\mathrm{mg} / 1$ at site $B$ and from 0.7 to $11.7 \mathrm{mg} / 1$ at site C. Concentrations of insoluble organic matter amounts varied between 0.1 and $7.2 \mathrm{mg} / 1$ at site $A$, between 0.9 and $4.6 \mathrm{mg} / 1$ at site $B$ and between 0.5 and $6.3 \mathrm{mg} / 1$ at site C (Table 6). Transparency of the water was low (Fig. 6 ), an inverse relationship being noticed between transparency of the water and the amount of suspended matter present at the three sample sites.

Dissolved oxygen was always below saturation levels (Fig. 6), the lowest and most variable values observed at site A (11.68 to $62.97 \%)$. Percent saturation from 37.65 to $78.02 \%$ were determined at site $B$, and from 46.04 to $71.58 \%$ at site C. Chlorophy11- $a$ concentrations varied from 1.89 to $16.57 \mu \mathrm{g} / 1$ at site $\mathrm{A}$, from 4.15 to $19.82 \mu \mathrm{g} / 1$ at site $B$ and from 2.67 to $31.13 \mu \mathrm{g} / 1$ at site C (Fig. 6). Amounts of pheophytin- $a$ varied from 0.73 to $12.24 \mathrm{\mu g} / 1$ at site $A$, from 2.97 to $10.52 \mu \mathrm{g} / 1$ at site $B$ and from 2.02 to $8.97 \mu \mathrm{g} / 1$ at site C (Fig. 6) denoting the presence of unhealthy or dead phytoplankton cells in the samples.

\section{Discussion}

Ciliates are tolerant with respect to several environmental factors (Corliss, 1973). Salinitity and temperature, usually the most important features determining the distribution of marine animals, are not as significant for the distribution of benthonic marine ciliates (Webb, 1956; Fenche1, 1969; Borror, 1975; Wilbert \& Kahan, 1981). Occurrence and local abundance of the species of ciliates are related to the type of available food (Noland, 1925 cit. in: Taylor \& Berger, 1976; Webb, 1956; Reid, 1969; Wilbert, 1969; Borror, 1975; Taylor, 1978) and to oxygen concentration (Stout, 1956; Taylor, 1979). At low levels of oxygen, number and amount of the aerobic species are reduced, even when abundant food reserves seem to be available (Wilbert, 1969; Bick, 1973).

The quicker colonization of the substrata by Zoothamnium colonies towards the headwaters of the estuary may be indirectly related to increasing amount of suspended matter. Peritrichous ciliates feed essentially on bacteria and when abundant they indicate an organically polluted environment (Parrish \& Lucas, 1970; Bick, 1973; Finley, 1974; Henebry \& Ridgeway, 1979). Bastida (1968) considers $Z$. commune an indicator of polluted waters since, in harbors, it increases in number with raising contamination. Z. commune was also the most frequent species observed on the primary growth of an internal place of the harbor at Genoa, Italy, polluted by urban wastes (Relini et al., 1976), and it was observed by Persoone (1968) in the harbor of Ostend, Be1gium, a polysaprobic estuary.

The unexpected low numbers of $Z$. commune in the January samples of site A seem to be related to low percentage of oxygen saturation (Fig. 6), instead of little amount of organic matter available, which was not the case (Table 6). Also during May and June, other periods of very low oxygen saturation levels at this sampling site, the density of Zoothamnium commune was low.

Vagile ciliates can not be responsible for the decreasing amount of $Z$. commune down the estuary for predators of peritrichs were sporadically found in great numbers, both at headwaters and 
Table 6 - Inorganic and organic fraction of the suspended matter $(\mathrm{mg} / \mathrm{l})$

\begin{tabular}{|c|c|c|c|c|c|c|c|}
\hline \multirow{2}{*}{\multicolumn{2}{|c|}{$\underbrace{\begin{array}{c}\text { Sampling } \\
\text { site }\end{array}}_{\text {Date }}$}} & \multicolumn{2}{|c|}{ A } & \multicolumn{2}{|c|}{ B } & \multicolumn{2}{|c|}{ C } \\
\hline & & $\begin{array}{c}\text { Inorganic } \\
\text { matter }\end{array}$ & organic & $\begin{array}{c}\text { inorganic } \\
\text { matter }\end{array}$ & organic & inorganic & organic \\
\hline Apr & 19,1979 & 9.8 & 5.0 & 5.5 & 2.9 & 6.0 & 6.3 \\
\hline Jun & 21 & 11.2 & 7.2 & 7.6 & 4.3 & 7.5 & 4.8 \\
\hline Jul & 05 & 8.4 & 3.4 & 6.9 & 4.6 & 5.3 & 6.1 \\
\hline Aug & 09 & 32.4 & 3.6 & 8.0 & 2.6 & 8.1 & 0.5 \\
\hline Aug & 23 & 16.5 & 2.7 & 20.2 & 3.8 & 6.2 & 1.0 \\
\hline $\mathrm{Oct}$ & 05 & 29.3 & 4.6 & 9.6 & 1.6 & 9.4 & 1.0 \\
\hline $0 c t$ & 19 & 11.2 & 3.6 & 8.5 & 2.7 & 11.7 & 0.9 \\
\hline Nov & 30 & 5.3 & 0.1 & 8.0 & 1.1 & 6.0 & 2.5 \\
\hline Dec & 14 & 6.5 & 2.3 & 4.9 & 2.8 & 4.4 & 3.8 \\
\hline Jan & 10,1980 & 7.3 & 4.8 & 4.9 & 3.9 & 0.7 & 2.8 \\
\hline Jan & 23 & 4.7 & 0.6 & 5.1 & 1.0 & 1.7 & 0.7 \\
\hline Mar & 07 & 57.1 & 6.1 & 5.8 & 0.9 & 5.7 & 0.8 \\
\hline
\end{tabular}

downstream. Also immigration was not being prevented since there was still space available for colonization when cover slips were removed from the water (Eston, 1981).

Decrease in the Acineta tuberosa numbers on consecutive days in the January samples of site C seems to be related to the reestablishment of the E. gemmipara population. As they are both carnivorous species (Gre11, 1973), competition for food between them or mutual predation on young stages shoud be investigated in order to understand their replacement on the cover slips.

Although short time variability was observed in the colonization of substrata submerged on subsequent days, seasonal patterns could be determined. They were characterized by higher densities of sessile ciliates and a greater number of the rare species during spring and summer. Increase in the mobility and reproductive rate during the warmer periods (see Schoener, 1974) was certainly responsible for the seasonal patterns observed. On the other hand, the local variability observed among replicate samples was probably caused by random colonization of the organisms (see Sutherland \& Kar1son, 1977).

\section{Conclusion}

The two types of association formed by the sessile ciliates denote the existence of different environmental conditions along the estuary of Santos. Shift in the dominance from Ephelota gemmipara to Zoothamnium commune towards the headwaters of this estuary seemed to be related to increasing amount of suspended matter in the water, whenever oxygen concentration levels were not extremely low.

\section{Acknowledgements}

This paper is based on a thesis submitted in partial fulfilment of the requirements for the Degree of Master in Biological Oceanography at the "Instituto Oceanográfico" of the University of São Paulo. I wish to acknowledge Luiz A. Zavala-Camin who provided laboratory space and facilities in Santos at the "Divisão de Pesca Maritima" of the "Instituto de Pesca da Secretaria da Agricultura do Estado de São Paulo" as well as the Fire-Brigade of Santos, for boat facilities. This research was possible thanks to FAPESP (Proc. no 1118/77) and CAPES fellowships.

\section{References}

BASTIDA, R. 1968. Las incrustaciones biologicas en el Puerto de Mar del Plata, período 1966/67 (1 a parte). La Plata, Laboratorio de Ensayo de Materiales e Investigaciones de $1 \mathrm{a}$ Provincia de Buenos Aires, 68 p. 
BICK, H. 1972. Ciliated protozoa: an illustrated guide to the species used as biological indicators in freshwater biology. Geneva, W. H. C., $198 \mathrm{p}$.

1973. Population dynamic of protozoa associated with decay of organic materials in fresh water. Am. Zool., 13:149-160.

BORROR, A. C. 1975. Environmental requirements of selected estuarine ciliated protozoa. Corvallis, U.S. Environmental Protection Agency, 49 p.

BURBANCK, W. D. \& SPOON, D. M. 1967. The use of sessile ciliates collected in plastic Petri dishes for rapid assessment of water pollution. J. Protozool., 14:739-744.

CAIRNS Jr, J.;KUHN, D. K. L. \& PLAFKIN, J. L. 1978. Protozoan colonization of artificial substrates. In: Weitze1, R. L., ed. Methods and measurements of periphyton commuties: a review. Philadelphia, ASTM, p. 34-57.

CORLISS, J. 0. 1973. Protozoan ecology: a note on its current status. Am. Zool., 13:145-148.

CURDS, C. R. 1969. An illustrated key to the British freshwater ciliated protozoa commonly found in activated sludge. Wat. Pollut. Res., 12:1-90.

DAVIS, J. C. 1973. Statistics and data analysis in geology. New York, John Wiley, 55 p.

DRAGESCO, J. 1962. Capture et ingestion des proies chez les infusoires ciliés. Bull. biol. Fr. Belg., 96: 123-167.

ESTON, V. R. de 1981. Recobrimento primārio de substratos artificiais submersos no estuário de Santos (São Paulo, Brasi1). Dissertação de mestrado. Instituto Oceanogräfico, Universidade de São Paulo, 116 p.

FAURE-FREMIET, E. 1961. Documents et observations écologiques et pratiques sur la culture des infusoires ciliés. Hydrobiologia, 18: 300-320.
FENCHEL, T. 1969. The ecology of marine microbenthos. IV - Structure and function of the benthic ecosystem, its chemical and physical factors and the microfauna communities with special references to the ciliated protozoa. Ophelia, 6:1-182.

FINLEY, H. E. 1974. The peritrichs now and then: 1676 to 1973. Trans. Am. micros. Soc., 93:307-313.

GENOVESE, S. \& GANGEMI, G. 1966. Primo contributo allo studio de forme fissate su vetrini immersi in un ambiente salmastro meromittico. Atti Soc. pelorit. Sci. fis. mat. nat., $12: 509-519$.

GOLDENSTEIN, L. 1972. A industrialização da Baixada Santista: estudo de um centro industrial satélite. Sér. Teses Monogr., Inst. Geogr. Univ. S Paulo, 7:1-342.

GRASSLE, J. F. \& SMITH, W. 1976. A similarity measure sensitive to the contribution of the rare species and its use in investigation of variation in marine benthic communities. Oecologia, 25:13-22.

GRELL, K. G. 1973. Protozoology. Berlin, Springer-Verlag, 554 p.

HENEBRY, M. S. \& CAIRNS Jr, J. 1980. Monitoring of stream pollution using protozoan communities on artificial substrates. Trans. Am. micros. Soc., 99:151-160.

\& RIDGEWAY, B. T.

1979.

Epizoic ciliated protozoa of planktonic copepods and cladocerans and their possible use as indicators of organic pollution. Trans. Am. micros. Soc., 98:495-508.

HEULEKIAN, H. \& CROSBY, E. S. 1956. Slime formation in polluted waters. III - Nature and composition of slimes. Sewage ind. Wastes, 28:206210 .

KAHL, A. 1935. Urtiere oder Protozoa. I- Wimpertiere oder Ciliata (Infusoria), eine Bearbeitung der freilebendem und ectocommensalen 
Infusorien der Erde, unter Ausschluss der warinen Tintinnidae. Tierwelt Dt1., 30:651-805.

MARCUS, M. D. 1980. Periphytic community response to chronic nutrient enrichment by a reservoir discharge. Ecology, 61: 387-399.

PARRISH, L. P. \& LUCAS, A. M. 1970. The effects of wastewaters on periphyton growths in the Missouri river. Cincinnati, U.S.F.W.P.C.A. Nat'1 Field Investigation Center, $26 \mathrm{p}$.

PATRICK, R.; HOHN, M. H. \& WALLACE, J. H. 1954. A new method for determining the pattern of the diatom flora. Notul. Nat., 259:1-12.

PERSOONE, G. 1968. Ecologie des infusoires dans les salissures de substrats immergés dans un port de mer. I- Le film primaire et le recouvrement primaire. Protistologica, $4: 187-194$.

1971. Ecology of fouling of submerged surfaces in a polluted harbor. Vie Milieu, 22 (supp1. 2): 613-639.

REID, R. 1969. Fluctuations in populations of 3 Vorticella species from an activated-sludge sewage plant. J. Protozool., 16:103-111.

RELINI, G.; MONTANARY, M.; VIALE, S. \& PISANO, E. 1976. Prime fasi de insediamento su substrati duri immersi in acque del porto di Genova a diverso grado de inquinamento. Archo Oceanogr. Limnol., 18 (suppl. 3) : 113-140.

SCHOENER, A. 1974. Colonization curves for planar marine islands. Ecology, $55: 818-827$.

SLĀDECKOVĀ, A. 1962. Limnological investigation methods for the periphyton ("Aufwuchs") community. Bot. Rev., 28:286-350.

SMALL, E. B. 1973. A study of ciliate protozoa from a small polluted stream in east-central Illinois. Am. Z.ool., 13:225-230.
SNEATH, P. H. A. \& SOKAL, R. R. 1973. Numerical taxonomy: the principles and practice of numerical classification. San Francisco, W. H, Freeman, 573 p.

STOUT, J. D. 1956. Reaction of ciliates to environmental factors. Ecology, 37:178-191.

SUTHERLAND, J. P. \& KARLSON, R. H. 1977. Development and stability of the fouling community at Beaufort, North Carolina. Ecol. Monogr., 47: 425-446.

TAYLOR, W. D. 1978. Growth responses of ciliates to the density of their bacterial prey. Microb. Ecol., 4: 207-214.

1979. Sampling data on the bactivorous ciliates of a small pond compared to neutral models of community structure. Ecology, 60: 876-883.

\& BERGER, J. 1976.

Growth responses of cohabiting ciliate protozoa to various prey bacteria. Can. J. Zool., 54:11111114.

TOMMASI, L. R. 1979. Considerações ecológicas sobre o sistema estuarino de Santos (SP). Tese de livre-docência. Universidade de São Paulo, Instituto Oceanogräfico, 489 p.

WEBB, M. 1956. An ecological study of brackish water ciliates. J. Anim. Ecol., 25:148-175.

WILBERT, N. 1969. Ökologische Untersuchung der Aufwuchs und Plankton-ciliaten eines eutrophen Weihers. Arch. Hydrobiol., (Supp1. 35):411-518.

\& KAHAN, D. 1981.

Ciliates of Solar Lake on the Red Sea shore. Arch. Protistenk., 124:70-95.
(Received 03-Jul-1984; accepted 07-May-1985) 